\title{
Erratum to: The effect of acute dose charge particle radiation on expression of DNA repair genes in mice
}

\author{
Muhammad Akram Tariq • Ayodotun Soedipe - Govindarajan T. Ramesh • \\ Honglu Wu $\cdot$ Ye Zhang $\cdot$ Shishir Shishodia • Daila S. Gridley • \\ Nader Pourmand $\cdot$ Olufisayo Jejelowo
}

Published online: 11 January 2011

(C) Springer Science+Business Media, LLC. 2011

\section{Erratum to: Mol Cell Biochem \\ DOI 10.1007/s11010-010-0641-0}

In the original article one of the authors has not been mentioned.

The author group should have read:

Muhammad Akram Tariq · Ayodotun Soedipe · Govindarajan T. Ramesh · Honglu Wu · Ye Zhang · Shishir Shishodia · Daila S. Gridley · Nader Pourmand · Olufisayo Jejelowo
The affiliation of the missing author is:

D. S. Gridley-Radiation Research Laboratories, Loma Linda University and Medical Center, Loma Linda, CA 92354, USA.

Further the name of the third author is not correctly displayed. His name is given as: G. Ramesh.

His correct name is G. T. Ramesh.

Everything else in the article remains correct.

The online version of the original article can be found under doi: 10.1007/s11010-010-0641-0.

M. A. Tariq · N. Pourmand $(\bowtie)$

Department of Biomolecular Engineering, University

of California, Santa Cruz, CA 95064, USA

e-mail: pourmand@soe.ucsc.edu

M. A. Tariq · A. Soedipe $\cdot$ S. Shishodia $\cdot$ O. Jejelowo Center for Bionanotechnology and Environmental Research, Texas Southern University, Houston, TX 77004, USA

A. Soedipe $\cdot$ S. Shishodia $\cdot$ O. Jejelowo

Department of Biology, Texas Southern University, Houston,

TX 77004, USA

G. T. Ramesh

Department of Biology, Norfolk State University, Norfolk,

VA 23504, USA

H. Wu · Y. Zhang

NASA Johnson Space Center, Houston, TX 77058, USA

D. S. Gridley

Radiation Research Laboratories, Loma Linda University

and Medical Center, Loma Linda, CA 92354, USA 